Journal of Agricultural Sciences
(Tarim Bilimleri Dergisi)

\title{
Effect of Ginger Essential Oil on in Vitro Gas Production, Rumen Fermentation and Methane Production
}

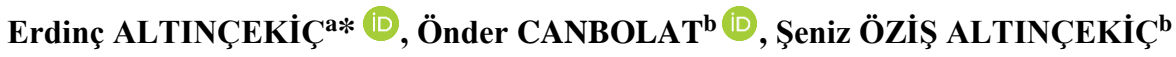

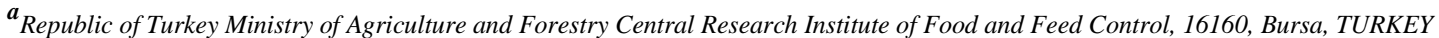 \\ $\boldsymbol{b}$ Department of Animal Science, Faculty of Agriculture, Bursa Uludag University, 16059, Bursa, TURKEY
}

ARTICLE INFO

Research Article

Corresponding Author: Erdinç ALTINÇEKİÇ, E-mail: ealtincekic@ gmail.com

Received: 09 May 2020 / Revised: 29 July 2020 / Accepted: 08 August 2020 / Online: 04 December 2021

ABSTRACT

In this study, control (0), 50,100, 200, 400, 800 and $1000 \mathrm{mg} \mathrm{L}^{-1}$ ginger essential oil (GEO) (Zingiber officinale Roscoe) was added to rumen liquid (RL). Then, the effects of the GEO added to the RL In vitro gas production, organic matter digestibility (OMD), metabolisable energy (ME), rumen fermentation parameters and methane $\left(\mathrm{CH}_{4}\right)$ production were examined on these samples. It was determined that the addition of the GEO to RL decreased the in vitro gas production of Trifolium pratense hay (TPH), the OMD and ME contents, total volatile fatty acids (TVFA), acetic acid (AA), propionic acid (PA), butyric acid (BA) and other volatile fatty acids $(\mathrm{OVFA})(\mathrm{P}<0.05)$. Moreover, it was determined that while the productions of carbon dioxide $\left(\mathrm{CO}_{2}\right), \mathrm{CH}_{4}$ and ammonia nitrogen $\left(\mathrm{NH}_{3-}\right.$ $\mathrm{N})$ decreased, the ratios of the rumen $\mathrm{pH}$ and $\mathrm{AA} / \mathrm{PA}$ increased $(\mathrm{P}<0.05)$ depending on the increase in the dose of GEO. In conclusion, it was determined that the GEO dose which had the highest negative effect on the in vitro gas production, the rumen fermentation, the nutrient digestibility, the $\mathrm{CH}_{4}$ and the $\mathrm{CO}_{2}$ production was $1000 \mathrm{mg} \mathrm{L}^{-1}$. It was concluded that since high doses of GEO affect rumen fermentation and digestion of feeds negatively, it would be appropriate to use $200 \mathrm{mg} \mathrm{L}^{-1}$.

Keywords: Ruminant nutrition, Zingiber, Rumen parameters, Methane, Fatty acids

(C) Ankara University, Faculty of Agriculture

\section{Introduction}

In livestock sector, antibiotics have been commonly used with the aim of increasing the feed conversation and preventing diseases and metabolic disorders (Jouany \& Morgavi 2007). However, the use of antibiotics in animal feeding was banned after January of 2006 as required by the decision made by the European Union in 2003 on the grounds that they pose a risk for human health (Chesson 2006). In order to solve this problem, the number of studies carried out with the aim of developing feed additives as an alternative to antibiotics has increased. As a result of these studies, it was put forward that aromatic plants and essential oils extracted from these plants would be an alternative to antibiotics (Chao et al. 2000; Meliani et al. 2014; Sharma et al. 2016; Mahboubi 2019).

There are many active metabolites such as zingiberene in the structure of the essential oils obtained from the ginger plant (Raina et al. 2005; Sharma et al. 2016). It is reported that these active compounds existing in the ginger essential oil (GEO) do not only have antiseptic, antimicrobial, antioxidant features, but they are also effective against common cold, vomiting control, heart diseases, stomach ulcers, tumor growth, rheumatism and migraine (Raina et al. 2005; Meliani et al. 2014; Mahboubi 2019). It is also stated that the GEO shows antibacterial feature against gram positive and gram negative bacteria (Chao et al. 2000; Meliani et al. 2014; Nanon et al. 2015; Faniyi et al. 2019).

It is reported that the GEO with above-mentioned features will be used to manipulate the rumen fermentation (Soroor $\&$ Moeini 2015; Faniyi et al. 2016; Kurniawati et al. 2018; Mekuiko Watsop et al. 2018; Faniyi et al. 2019). Moreover, it was also determined that the GEO has an effect on the digestibility of feeds, metabolisable energy (ME) and methane $\left(\mathrm{CH}_{4}\right)$ production (Nanon et al. 2015; Soroor \& Moeini 2015; Kurniawati et al. 2018; Mekuiko Watsop et al. 2018; Faniyi et al. 2019). For this reason, it is important to reveal the effects of GEO on rumen fermentation, digestion of feeds and the $\mathrm{CH}_{4}$ production in rumen.

This study was carried out with the aim of determining the effects of different doses of GEO (0, 50, 100, 200, 400, 800 and $1000 \mathrm{mg} \mathrm{L}^{-1}$ to rumen liquid (RL)) on in vitro gas production, the digestibility of feeds, the rumen fermentation and $\mathrm{CH}_{4}$ production. 


\section{Material and Methods}

\subsection{Feed and animal material}

The feed material of the study was Trifolium pratense hay (TPH) and it was used in the study after being ground in the grinder with a sieve-diameter of $1 \mathrm{~mm}$. The GEO used in the study was obtained from the market in pure form (catalogue no: W2522048007-08-7) (Sigma-Aldrich). The RL used in the study was taken from 3 rams, Kivircik breed, with a rumen canula. During the study, the animals were fed with complete ration (TMR) composed of $60 \%$ of alfalfa hay and $40 \%$ of concentrate feed mix (18\% crude protein and $2750 \mathrm{kcal} \mathrm{kg}^{-1} \mathrm{ME}$ Dry $\left.\mathrm{Matter}^{-1}(\mathrm{DM})\right)$ and water was continuously available in front of them.

\subsection{Implementation of in vitro gas production technique}

In the determination of the TPH's in vitro gas production and the levels of organic matter digestibility (OMD) and ME, the in vitro gas production technique developed by Menke \& Steingass (1988) was used. In order to determine the in vitro gas production, special glass tubes with a volume of $100 \mathrm{~mL}$ (Model Fortuna, Häberle Labortechnik, Lonsee-Ettlenschie $\beta$, Germany) were used and about $200 \pm 10 \mathrm{mg}$ of feed samples were put into the syringes for each dose of GEO $(0,50,100,200,400,800$ and $1000 \mathrm{mg} \mathrm{L}^{-1}$ to RL) in triplicates. $30 \mathrm{~mL}$ of RL/buffer solution prepared in accordance with the method reported by Menke et al. (1979) was added into the syringes. Following this procedure, the syringes were taken into incubation in the water bath of $39^{\circ} \mathrm{C}$ and the in vitro gas productions were measured at the intervals of 3, 6, 12, 24, 48, 72 and 96 hours, respectively.

At the 96 hours of the incubation, the $\mathrm{pH}$, the total volatile fatty acid (TVFA) and the ammonia nitrogen $\left(\mathrm{NH}_{3}-\mathrm{N}\right)$ levels in the RL in the syringes were determined. Moreover, the carbon dioxide $\left(\mathrm{CO}_{2}\right)$ and the $\mathrm{CH}_{4}$ gases produced were calculated using the concentration of the individual volatile fatty acids (VFA) via the following equations (Blümmel et al. 1999).

$\mathrm{CO}_{2}=$ Acetic acid (AA)/ $2+$ Propionic acid (PA)/ $4+1.5 \times$ Butyric acid (BA)

$\mathrm{CH}_{4}=(\mathrm{AA}+2 \times \mathrm{BA})-\mathrm{CO}_{2}$

The concentration of VFA was taken as mmol.

The OMD of the feed raw materials and their ME were determined via the following equations reported by Menke \& Steingass (1988).

OMD, $\%=15.38+0.8453 \times \mathrm{GP}+0.0595 \times \mathrm{VP}+0.0675 \times \mathrm{CA}$

$\mathrm{ME}, \mathrm{MJ} / \mathrm{kg} \mathrm{DM}=2.20+0.1357 \times \mathrm{GP}+0.0057 \times \mathrm{CP}+0.0002859 \times \mathrm{EE}^{2}$

(GP: The net gas production at the end of the 24-hour of incubation duration of $200 \mathrm{mg}$ of dry forage sample, CP: $\%$ Crude protein, EE: \% Ether extract and CA: \% Crude ash).

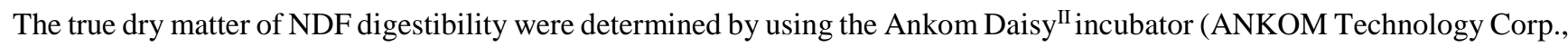
Fairport, NY, USA, 2008).

\subsection{Chemical analysis}

The dry matter, CA, CP and EE analyses of TPH were determined with the methods reported by AOAC (2000); the analysis of the cell wall components was determined with the methods reported by Van Soest et al. (1991) using the ANKOM 200 Fiber Analyzer device (ANKOM Technology Corp., Fairport, NY, USA, 2008).

The $\mathrm{pH}$ of the RL was determined via a digital pH-meter (Sartorius PB-20, Goettingen, Germany). Ruminal ammonia nitrogen $\left(\mathrm{NH}_{3}-\mathrm{N}\right)$ analysis was done in $\mathrm{RL}$ used in in vitro gas production at $96^{\text {th }}$ hour. $\mathrm{RL}$ was taken $10 \mathrm{~mL}$ and put into tubes $(15 \mathrm{~mL})$. Then, $0.1 \mathrm{~mL}$ of $1 \mathrm{M}$ hydrochloric acid (HCI) was added to stop the microorganism activity. Ruminal $\mathrm{NH}_{3}-\mathrm{N}$ analysis was distilled by Kjeldahl method. For this purpose, $10 \mathrm{~mL}$ of RL was placed in the sample setting unit of the Kjeldahl device and $3 \mathrm{~mL}$ of $1 \mathrm{~N}$ sodium hydroxide $(\mathrm{NaOH})$ solution was added. For distillate $50 \mathrm{~mL}$ of $2 \%$ boric acid was placed and 3-4 drops of indicator were placed on it. Subsequently, $175 \mathrm{~mL}$ of distillate were collected. The distillate collected was titrated with $0.1 \mathrm{~N}$ sulfuric acid $\left(\mathrm{H}_{2} \mathrm{SO}_{4}\right)$. The amount of sulfuric acid spent in titration $(\mathrm{mL})$ was determined. Then $\mathrm{NH}_{3}-\mathrm{N}$ was calculated in mg (Blümmel et al. 1997).

RL volatile fatty acids (acetic, butyric, propionic, valaric, isovaleric and isobutyric acid) analysis was done in RL used in in vitro gas production at $96^{\text {th }}$ hour. $\mathrm{RL}$ was taken $10 \mathrm{~mL}$ and put into tubes $(15 \mathrm{~mL})$. Then, $1.0 \mathrm{~mL}$ of $25 \%$ phosphoric acid was added to RL (Wiedmeier et al. 1987). RL was centrifuged at $14000 \mathrm{rpm}$ and determined by gas chromatography (Agilent Technologies $6890 \mathrm{~N}$ gas chromatography, Stabilwax-DA, $30 \mathrm{~m}, 0.25 \mathrm{~mm}$ ID, 0.25 um df. Max. Temp: $260{ }^{\circ} \mathrm{C}$. Cat. 11023 ) RL volatile fatty acids.

\subsection{Statistical analyses}

The research was conducted by a completely randomized design with three replications. The data obtained from the research was subjected to analysis of variance (Snedecor \& Cochran 1967) and the differences between means was determined with 
Duncan multiple comparison test using SAS programme (2004).

\section{Results and Discussion}

\subsection{Chemical composition of TPH}

The organic matter, CA, CP, EE, NDF, ADF, ADL, cellulose and hemicellulose contents of TPH were calculated as 93.82\%, $6.18,17.38,3.81,51.08,36.66,8.56,14.43$ and 28.10 respectively. The chemical composition of TPH was found similar to that reported by NRC (2007).

Table 1- Chemical composition of TPH, \%

\begin{tabular}{lr}
\hline Ingredients & $\%$ \\
\hline Organic matters & 93.82 \\
Crude ash & 6.18 \\
Crude protein & 17.38 \\
Ether extract & 3.81 \\
Neutral detergent fiber, (NDF) & 51.08 \\
Acid detergent fiber, (ADF) & 36.66 \\
Acid detergent lignin, (ADL) & 8.56 \\
Cellulose & 28.10 \\
Hemicellulose & 14.43 \\
\hline
\end{tabular}

\subsection{Effect of GEO on in vitro gas production}

The GEO addition decreased the in vitro gas production of TPH in all the incubation periods $(\mathrm{P}<0.05)$. The lowest in vitro gas production was found in the group with $64.89 \mathrm{~mL}$ and $1000 \mathrm{mg} \mathrm{L}^{-1}$ addition and the highest in vitro gas production was found in the control group with $74.66 \mathrm{~mL}$ and without GEO addition. The decrease in the in vitro gas production occurring depending on the increase in the GEO dose added to RL can be explained by the antimicrobial features of active components existing in the structure of GEO and, as a result of this, their limiting rumen microorganisms (Chao et al. 2000; Meliani et al. 2014; Nanon et al. 2015; Soroor \& Moeini 2015; Kurniawati et al. 2018; Mekuiko Watsop et al. 2018; Faniyi et al. 2019). In many previous studies, it was reported that GEO decreased the in vitro gas production (Tag El-Din et al. 2012; Meliani et al. 2014; Nanon et al. 2015; Soroor \& Moeini 2015; Kurniawati et al. 2018; Mekuiko Watsop et al. 2018; Faniyi et al. 2019). The findings of this study support the results reported by Tag El-Din et al. (2012), Kurniawati et al. (2018), Mekuiko Watsop et al. (2018). However, Nanon et al. (2015) showed that GEO addition (1600 mg/kg DM) affected the in vitro gas production negatively.

Table 2- Effects of GEO and its different doses on the in vitro gas production of TPH, mL

\begin{tabular}{lllllllll}
\hline \multirow{2}{*}{$\begin{array}{l}\text { Incubation } \\
\text { duration, hour }\end{array}$} & \multicolumn{7}{c}{ GEO, $m g L^{-1}$} \\
\cline { 2 - 8 } & Control $(0)$ & 50 & 100 & 200 & 400 & 800 & 1000 & $S E M^{*}$ \\
\hline 3 & $18.80^{\mathrm{a}}$ & $18.41^{\mathrm{ab}}$ & $17.83^{\mathrm{ab}}$ & $17.35^{\mathrm{b}}$ & $16.17^{\mathrm{c}}$ & $14.95^{\mathrm{d}}$ & $14.48^{\mathrm{d}}$ & 0.625 \\
6 & $29.76^{\mathrm{a}}$ & $28.65^{\mathrm{b}}$ & $27.77^{\mathrm{bc}}$ & $27.65^{\mathrm{c}}$ & $25.48^{\mathrm{d}}$ & $23.90^{\mathrm{e}}$ & $22.71^{\mathrm{f}}$ & 0.549 \\
12 & $45.43^{\mathrm{a}}$ & $44.47^{\mathrm{ab}}$ & $43.14^{\mathrm{bc}}$ & $41.29^{\mathrm{cd}}$ & $40.29^{\mathrm{d}}$ & $39.21^{\mathrm{d}}$ & $36.71^{\mathrm{e}}$ & 1.268 \\
24 & $57.77^{\mathrm{a}}$ & $56.02^{\mathrm{b}}$ & $55.34^{\mathrm{b}}$ & $63.60^{\mathrm{c}}$ & $51.76^{\mathrm{d}}$ & $49.93^{\mathrm{e}}$ & $48.67^{\mathrm{e}}$ & 0.880 \\
48 & $67.70^{\mathrm{a}}$ & $64.61^{\mathrm{b}}$ & $61.36^{\mathrm{c}}$ & $59.18^{\mathrm{cd}}$ & $57.65^{\mathrm{de}}$ & $55.67^{\mathrm{e}}$ & $53.11^{\mathrm{f}}$ & 1.401 \\
72 & $71.62^{\mathrm{a}}$ & $70.06^{\mathrm{b}}$ & $69.62^{\mathrm{bc}}$ & $68.42^{\mathrm{cd}}$ & $67.41^{\mathrm{d}}$ & $65.86^{\mathrm{e}}$ & $63.33^{\mathrm{f}}$ & 0.746 \\
96 & $74.66^{\mathrm{a}}$ & $72.22^{\mathrm{b}}$ & $71.10^{\mathrm{c}}$ & $69.55^{\mathrm{d}}$ & $69.16^{\mathrm{de}}$ & $68.25^{\mathrm{e}}$ & $64.89^{\mathrm{f}}$ & 0.608 \\
\hline
\end{tabular}

*: Standard error mean. Differences between the means shown with different letters on the same line are significant $(\mathrm{P}<0.05)$

The positive effect of the GEO added to RL on the digestibility of feeds can be explained by the GEO's showing antimicrobial activity against microorganisms (Tag El-Din et al. 2012; Kurniawati et al. 2018; Mekuiko Watsop et al. 2018). The organic components existing in GEO are reported to show an antibacterial effect by breaking the cell wall structure of microorganisms as it is in other essential oils (Sharma et al. 2016; Mahboubi 2019). It can be stated that the development of rumen microorganisms is limited via a similar mechanism (Tag El-Din et al. 2012; Soroor \& Moeini 2015; Kurniawati et al. 2018; Mekuiko Watsop et al. 2018) and, depending on this, in vitro gas production decreases.

\subsection{Effect of GEO on the OMD and $M E$}

Supplementation of GEO significantly affected OMD and ME content of TPH. The OMD and ME content ranged from \% 78.72 to 71.03 and 11.44 to $10.21 \mathrm{MJ} / \mathrm{kg} \mathrm{DM}$ respectively $(\mathrm{P}<0.05)$. These parameters significantly decreased with increasing level of GEO supplementation. 
Table 3- Effects of GEO and its different doses on the OMD of TPH under in vitro conditions and ME

\begin{tabular}{lllllllll}
\hline \multirow{2}{*}{ Parameters } & \multicolumn{7}{c}{ GEO, $m g L^{-1}$} \\
\cline { 2 - 8 } & Control $(0)$ & 50 & 100 & 200 & 400 & 800 & 1000 & SEM $^{*}$ \\
\hline OMD, \% & $78.72^{\mathrm{a}}$ & $77.25^{\mathrm{b}}$ & $76.67^{\mathrm{b}}$ & $75.20^{\mathrm{c}}$ & $73.65^{\mathrm{e}}$ & $72.10^{\mathrm{e}}$ & $71.03^{\mathrm{e}}$ & 0.743 \\
$\mathrm{ME}, \mathrm{MJ} / \mathrm{kg} \mathrm{DM}$ & $11.44^{\mathrm{a}}$ & $11.21^{\mathrm{b}}$ & $11.11^{\mathrm{b}}$ & $10.88^{\mathrm{c}}$ & $10.63^{\mathrm{d}}$ & $10.38^{\mathrm{e}}$ & $10.21^{\mathrm{e}}$ & 0.118 \\
\hline
\end{tabular}

OMD: Organic matter digestion; ME: Metabolisable energy; ${ }^{*}$ : Standard error mean. Differences between the means shown with different letters on the same line are significant $(\mathrm{P}<0.05)$.

It can be explained by the finding that the GEO added to RL in increasing doses caused a low level of in vitro gas production by showing antimicrobial effect (Tag El-Din et al. 2012; Kurniawati et al. 2018; Mekuiko Watsop et al. 2018; Mahboubi 2019). However, Soroor \& Moeini (2015) found that the GEO increased the in vitro gas production. The finding that the in vitro gas production was found high in the mentioned study can be explained by the use of a different ration and the low dose of GEO (60 $\left.\mathrm{mg} \mathrm{L}^{-1}\right)$.

The decrease in the OMD determined in the study was also found in the studies made by Tag El-Din et al. (2012) and Mekuiko Watsop et al. (2018), Mahboubi (2019) working with different feeds and GEO doses. However, in the studies carried out by Soroor \& Moeini (2015), Medjekal et al. (2017) and Kurniawati et al (2018), the GEO affected the digestibility of feeds positively. This can be explained by the fact that these researchers worked with low doses $\left(60 \mathrm{mg} \mathrm{L}^{-1}, 50 \mathrm{mg} \mathrm{L}^{-1} \mathrm{and} 100 \mathrm{mg}\right.$ $\mathrm{L}^{-1}$, respectively). Nanon et al (2015) reported in their study that the GEO addition (1600 $\mathrm{mg} / \mathrm{kg}$ DM) to the ration did not affect the digestion of dry matter negatively.

With the GEO addition in different doses to RL, the ME content of TPH changed between 11.44 and 10.21 MJ/kg DM. As the GEO dose increased, the ME level decreased. Similarly, Tag El-Din et al. (2012) determined in their study that the addition of ginger decreased the ME level.

\subsection{Effect of GEO on rumen fermentation}

The addition of GEO to RL decreased the TVFA and the AA, PA and BA significantly $(\mathrm{P}<0.05)$. Depending on the GEO doses, the TVFA ranged from 90.05 to $68.88 \mathrm{mmol} / \mathrm{L}$. The lowest TVFA was determined in the experimental group into which the GEO was added in the dose of $1000 \mathrm{mg} \mathrm{L}^{-1}$. Moreover, the AA, PA and BA levels of RL varied between 47.92-35.69 mmol/L, 21.13-18.37 mmol/L and 15.39-7.56 mmol/L, respectively. The most effective GEO dose on TVFA, AA, PA and BA was determined as $1000 \mathrm{mg} \mathrm{L}^{-1}(\mathrm{P}<0.05)$. The addition of GEO to RL affected the rumen fermentation significantly. This can be explained by the finding that GEO had an antibacterial effect on the rumen microorganisms (Tag El-Din et al. 2012; Kurniawati et al. 2018; Mekuiko Watsop et al. 2018; Mahboubi 2019). Especially, the increase in the GEO dose decreased the production of TVFA and the individual VFA. In their study, Soroor \& Moeini (2015) added 30 and 60 mg of GEO to RL and reported as a result of the study that the propionic acid rate increased, but the TVFA and AA rates decreased depending on the increase in the GEO doses. Similar findings were found in the study reported by Tag El-Din et al. (2012) in relation to the TVFA, too. However, Nanon et al. (2015) reported in their study that the GEO did not affect the contents of TVFA, AA and PA.

Table 4- Effects of GEO and its different doses on the features of rumen fermentation

\begin{tabular}{|c|c|c|c|c|c|c|c|c|}
\hline \multirow{2}{*}{$\begin{array}{l}R L \\
\text { Parameters }\end{array}$} & \multicolumn{7}{|c|}{$G E O, m g L^{-1}$} & \multirow[b]{2}{*}{$S E M^{*}$} \\
\hline & Control $(0)$ & 50 & 100 & 200 & 400 & 800 & 1000 & \\
\hline $\mathrm{pH}$ & $5.99^{\mathrm{f}}$ & $6.08^{\mathrm{e}}$ & $6.10^{\mathrm{e}}$ & $62.27^{\mathrm{d}}$ & $6.36^{\mathrm{c}}$ & $6.45^{\mathrm{b}}$ & $6.57^{\mathrm{a}}$ & 0.026 \\
\hline $\mathrm{NH}_{3} \mathrm{~N}, \mathrm{mg} \mathrm{N} / 100 \mathrm{~mL}$ & $31.31^{\mathrm{a}}$ & $31.52^{\mathrm{a}}$ & $29.23^{\mathrm{b}}$ & $28.28^{\mathrm{b}}$ & $24.03^{c}$ & $23.66^{\mathrm{c}}$ & $21.28^{\mathrm{d}}$ & 1.081 \\
\hline TVFA, mmol/L & $90.05^{\mathrm{a}}$ & $86.38^{\mathrm{b}}$ & $84.40^{c}$ & $80.55^{\mathrm{d}}$ & $75.68^{\mathrm{e}}$ & $72.03^{\mathrm{f}}$ & $68.88^{\mathrm{g}}$ & 1.068 \\
\hline $\mathrm{AA}, \mathrm{mmol} / \mathrm{L}$ & $47.92^{\mathrm{a}}$ & $46.27^{\mathrm{ab}}$ & $44.91^{\mathrm{b}}$ & $40.43^{c}$ & $35.69^{d}$ & $38.12^{\mathrm{c}}$ & $39.13^{c}$ & 1.348 \\
\hline $\mathrm{PA}, \mathrm{mmol} / \mathrm{L}$ & $20.07^{\mathrm{a}}$ & $19.04^{\mathrm{abc}}$ & $21.13^{b}$ & $18.62^{\mathrm{bc}}$ & $18.37^{\mathrm{c}}$ & $19.65^{\mathrm{ab}}$ & $19.67^{\mathrm{b}}$ & 0.595 \\
\hline $\mathrm{BA}, \mathrm{mmol} / \mathrm{L}$ & $13.55^{\mathrm{a}}$ & $13.29^{\mathrm{a}}$ & $13.39^{\mathrm{a}}$ & $15.39^{\mathrm{a}}$ & $15.15^{\mathrm{a}}$ & $10.68^{b}$ & $7.56^{\mathrm{c}}$ & 1.199 \\
\hline OVFA, mmol/L & $8.47^{\mathrm{a}}$ & $7.78^{\mathrm{ab}}$ & $7.48^{\mathrm{b}}$ & $6.36^{c}$ & $6.44^{c}$ & $3.58^{\mathrm{d}}$ & $2.2^{\mathrm{e}}$ & 0.392 \\
\hline $\mathrm{AA} / \mathrm{PA}$ & $2.38^{\mathrm{a}}$ & $2.43^{\mathrm{a}}$ & $2.13^{\mathrm{b}}$ & $2.20^{\mathrm{b}}$ & $1.95^{\mathrm{c}}$ & $1.94^{\mathrm{c}}$ & $1.99^{c}$ & 0.099 \\
\hline
\end{tabular}

$\mathrm{NH}_{3} \mathrm{~N}$ : Ammonia nitrogen; TVFA: Total volatile fat acids; OVFA: Other volatile fat acids; AA/PA: acetic acid/propionic acid; *: Standard error mean. Differences between the means shown with different letters on the same line are significant $(\mathrm{P}<0.05)$

The rate of AA/PA determined in the study varied between 2.38 and 1.94 depending on the increase in the GEO dose and the differences between the GEO doses were found significant $(\mathrm{P}<0.05)$. The highest AA/PA rate was found in the control group not including GEO. The AA/PA rate determined in the study was found lower than the values of (3.33-3.34) obtained by Nanon et al. (2015) working with GEO and the ones (2.3-2.6) determined by Soroor \& Moeini (2015) but higher than the values (1.81.7) reported by Benchaar et al. (2008) working with a different essential oil (garlic essential oil). 
Depending on the GEO dose, RL pH level varied between 5.99 and 6.57 and the differences between the GEO doses were found significant $(\mathrm{P}<0.05)$. The highest rumen $\mathrm{pH}$ was found in the group including $1000 \mathrm{mg} \mathrm{L}^{-1}$. That the $\mathrm{pH}$ increased depending on the increase in the GEO dose can be explained by the finding that the GEO addition decreased the VFA turning the RL into an acid character (Table 4). While the rumen $\mathrm{pH}$ determined in the study was found lower than the ones found by Kurniawati et al. (2018) working with GEO, it was found similar to the results reported by Busquet et al. (2006).

Moreover, ruminal $\mathrm{NH}_{3} \mathrm{~N}$ level changed between 31.31 and $21.28 \mathrm{mg} \mathrm{N} / 100 \mathrm{~mL}$ depending on the increase in the GEO dose. The highest $\mathrm{NH}_{3} \mathrm{~N}$ levels were determined in the control and $50 \mathrm{mg} \mathrm{L}^{-1}$ group not including GEO with the value of 31.31 and $31.52 \mathrm{mg} \mathrm{N} / 100 \mathrm{~mL}$ and the lowest $\mathrm{NH}_{3} \mathrm{~N}$ level was determined in the group including $1000 \mathrm{mg} \mathrm{L}^{-1}$ with the value of $21.28 \mathrm{mg}$ $\mathrm{N} / 100 \mathrm{~mL}(\mathrm{P}<0.05)$. The decrease in $\mathrm{NH}_{3} \mathrm{~N}$ level resulted initially from the decrease in the activity of RL microorganisms as well as the essential oils' preventing the deamination of amino acids (Nanon et al. 2015; Soroor \& Moeini 2015). It is reported that the decrease in the nitrogen loss in the rumen in the form of ammonia $\left(\mathrm{NH}_{3}\right)$ will be beneficial in terms of animal feeding and increase the benefiting from the energy and nitrogen of the feed (Nanon et al. 2015; Soroor \& $\mathrm{Moeini}_{2015}$ ). $\mathrm{NH}_{3} \mathrm{~N}$ level determined in the study was lower than the results reported by Nanon et al. (2015) working with GEO, but it was similar to the findings obtained by Soroor \& Moeini (2015). Mekuiko Watsop et al. (2018) reported in their study that the GEO addition decreased $\mathrm{NH}_{3} \mathrm{~N}$ level. Busquet et al. (2006) reported that the GEO addition to RL did not affect $\mathrm{NH}_{3} \mathrm{~N}_{\text {level. }}$.

\subsection{Effect of $\mathrm{GEO}$ on $\mathrm{CO}_{2}$ and $\mathrm{CH}_{4}$ gas production}

In the study, depending on the increase in the dose of GEO added to RL, the in vitro $\mathrm{CO}_{2}$ gas production decreased (P<0.05). The highest $\mathrm{CO}_{2}$ gas production was found in the control group with the value of $49.30 \mathrm{mmol} / \mathrm{L}$ and the lowest $\mathrm{CO}_{2}$ gas production was determined in the $1000 \mathrm{mg} \mathrm{L}^{-1}$ group with the value of $38.11 \mathrm{mmol} / \mathrm{L}(\mathrm{P}<0.05)$. Moreover, the in vitro $\mathrm{CH}_{4}$ gas production decreased depending on the GEO dose increase, varied between 25.18 and $18.43 \mathrm{mmol} / \mathrm{L}$ and the differences between then were found significant $(\mathrm{P}<0.05)$.

Table 5- Effects of GEO and its different doses on $\mathrm{CO}_{2}$ and $\mathrm{CH}_{4}$ productions

\begin{tabular}{lllllllll}
\hline & \multicolumn{7}{c}{ GEO, $m g L^{-1}$} \\
\cline { 2 - 8 } Parameters & Control $(0)$ & 50 & 100 & 200 & 400 & 800 & 1000 & $S E M^{*}$ \\
\hline $\mathrm{CO}_{2}, \mathrm{~mol} / \mathrm{L}$ & $49.30^{\mathrm{a}}$ & $47.89^{\mathrm{a}}$ & $57.83^{\mathrm{a}}$ & $47.19^{\mathrm{ab}}$ & $45.17^{\mathrm{b}}$ & $39.99^{\mathrm{c}}$ & $35.83^{\mathrm{c}}$ & 1.365 \\
$\mathrm{CH}_{4}, \mathrm{~mol} / \mathrm{L}$ & $25.18^{\mathrm{a}}$ & $25.01^{\mathrm{ab}}$ & $24.49^{\mathrm{b}}$ & $23.32^{\mathrm{c}}$ & $20.82^{\mathrm{d}}$ & $19.49^{\mathrm{e}}$ & $18.43^{\mathrm{f}}$ & 0.537 \\
\hline
\end{tabular}

*: Standard error mean. Differences between the means shown with different letters on the same line are significant $(\mathrm{P}<0.05)$.

The $\mathrm{CO}_{2}$ and $\mathrm{CH}_{4}$ productions in the ruminants are made by the methanogenic bacteria existing in the rumen via the use of VFA and hydrogen ions $\left(\mathrm{H}^{+}\right)$(Demeyer et al. 1996; Nanon et al. 2015). GEO decreases the $\mathrm{CH}_{4}$ gas formation by showing an antimicrobial effect on methanogenic bacteria, as it has on other rumen bacteria. $\mathrm{CH}_{4}$ is one of the most important greenhouse gases. It is reported that the greenhouse effect of $\mathrm{CH}_{4}$ is 23 times as much as that of $\mathrm{CO}_{2}$ (Kim et al. 2012). It is also reported that the contribution of farm animals to the emission of greenhouse gases is $18 \%$. It was determined that about $15 \%$ of this part resulted from the fermentation occurring in the rumens and manures of ruminant animals (Takahashi et al. 2005).

It is reported that $2-15 \%$ of feed energy is lost in the form of $\mathrm{CH}_{4}$ via the fermentation of feeds in rumen (Kim et al. 2012). It is stated that essential oils have a potential in decreasing energy loss and greenhouse gas emission via $\mathrm{CH}_{4}$ gas $(\mathrm{Chaouki}$ Benchaar \& Greathead 2011; Nanon et al. 2015; Ratika \& Singh 2018). It was also revealed in many previous studies that GEO led to the decrease in $\mathrm{CH}_{4}$ production by limiting the number of methane-producing bacteria in rumen (Tag El-Din et al. 2012; Nanon et al. 2015). In the study, the GEO addition in different doses to RL decreased the in vitro $\mathrm{CH}_{4}$ gas production significantly $(\mathrm{P}<0.05)$. These results show similarity to the findings obtained by Tag El-Din et al. (2012) and Kurniawati et al. (2018) working with GEO and the ginger plant.

\section{Conclusions}

In conclusion, the addition of GEO in different doses to RL under in vitro conditions decreased the in vitro gas production and OMD and the ME content significantly $(\mathrm{P}<0.05)$. Similarly, the increase in the dose of GEO added to RL decreased the TVFA and the individual VFA, two of the rumen metabolites, and the production of $\mathrm{NH}_{3} \mathrm{~N}, \mathrm{CO}_{2}$ and $\mathrm{CH}_{4}$ gases but increased the rumen $\mathrm{pH}$. It can be stated that GEO can prevent nitrogen loss in the rumen by decreasing $\mathrm{NH}_{3} \mathrm{~N}$ level in the rumen and it can be benefited from the feed energy more effectively by decreasing the loss of $\mathrm{CH}_{4}$ gas. However, since feeds negatively affect $\mathrm{OMD}$ and ME content, it is recommended to use GEO at low doses $\left(200 \mathrm{mg} \mathrm{L}^{-1}\right)$ in ruminant feeding. It was concluded that more in vitro and in vivo studies with more intensive content are needed to shed light on the matter.

\section{Disclosure statement}

No potential conflict of interest was reported by the authors. 


\section{References}

AOAC (2000). Official Methods of Analysis $17^{\text {th }}$ Edition. Arlington, VA, USA: Association of Official Analytical Chemists. ISBN: 093558467-6

Benchaar C \& Greathead H (2011). Essential oils and opportunities to mitigate enteric methane emissions from ruminants. Animal Feed Science and Technology 166-167: 338-355 https://doi.org/10.1016/j.anifeedsci.2011.04.024

Benchaar C, Calsamiglia S, Chaves A V, Fraser G R, Colombatto D, McAllister T A \& Beauchemin K A (2008). A review of plant-derived essential oils in ruminant nutrition and production. Animal Feed Science and Technology 145(1-4): 209-228 https://doi.org/10.1016/j.anifeedsci.2007.04.014

Blümmel M, Steingass H \& Becker K (1997). The relationship between in vitro gas production, in vitro microbial biomass yield and $15 \mathrm{~N}$ incorporation and its implications for the prediction of voluntary feed intake of roughages. British Journal of Nutrition (6): 911921https://doi.org/10.1079/bjn19970089

Blümmel M, Aiple K P, Steingaß H \& Becker K (1999). A note on the stoichiometrical relationship of short chain fatty acid production and gas formation in vitro in feedstuffs of widely differing quality. Journal of Animal Physiology and Animal Nutrition 81(3): 157-167 https://doi.org/10.1046/j.1439-0396.1999.813205.x

Busquet M, Calsamiglia S, Ferret A \& Kamel C (2006). Plant extracts affect in vitro rumen microbial fermentation. Journal of Dairy Science 89(2): 761-771 https://doi.org/10.3168/jds.S0022-0302(06)72137-3

Chao S C, Young D G \& Oberg C J (2000). Screening for inhibitory activity of essential oils on selected bacteria, fungi and viruses. Journal of Essential Oil Research 12(5): 639-649 https://doi.org/10.1080/10412905.2000.9712177

Chesson A (2006). Phasing out antibiotic feed additives in the EU: Worldwide relevance for animal food production. In: Barug D, de Jong J, Kies AK, Verstegen MWA, eds. Antimicrobial Growth Promoters: Where Do We Go from Here?. The Netherlands: Wageningen Academic Publishers, pp. 69-81

Demeyer D I, Fiedler D \& De Graeve K G (1996). Attempted induction of reductive acetogenesis into the rumen fermentation in vitro. Reproduction Nutrition Development 36(3): 233-240 https://doi.org/10.1051/rnd:19960301

Faniyi T O, Adewumi M K, Prates E R \& Ayangbenro A Segun (2016). Effect of herbs and spices (plant extracts) on rumen microbial activities: A review. Pubvet 10(6): 477-486 https://doi.org/10.22256/pubvet.v10n6.477-486

Faniyi T O, Prates Ê R, Adegbeye M J, Adewumi M K, Elghandour M M M Y, Salem A Z M, Ritt L A, Zubieta A S, Stella L, Ticiani E \& Jack A A (2019). Prediction of biogas and pressure from rumen fermentation using plant extracts to enhance biodigestibility and mitigate biogases. Environmental Science and Pollution Research 26(26): 27043-27051 https://doi.org/10.1007/s11356-019-05585-1

Jouany J P \& Morgavi D P (2007). Use of "natural" products as alternatives to antibiotic feed additives in ruminant production. Animal 1(10): 1443-1466 https://doi.org/10.1017/S1751731107000742

Kim E T, Kim C, Min K \& Lee S S (2012). Effects of plant extracts on microbial population, methane emission and ruminal fermentation characteristics in vitro. Asian-Australasian Journal of Animal Sciences 25(6): 806-811 https://doi.org/10.5713/ajas.2011.11447

Kurniawati A, Widodo W, Artama W T \& Yusiati L M (2018). Study of local herb potency as rumen modifier: the effect of red ginger (zingiber officinale var.rubrum) on parameters of ruminal fermentation in vitro. IOP Conference Series Earth Environmental Science 119(1): 0-8 https://doi.org/10.1088/1755-1315/119/1/012058

Mahboubi M (2019). Zingiber officinale Rosc. essential oil, a review on its composition and bioactivity. Clinical Phytoscience 5(1): 1-12 https://doi.org/10.1186/s40816-018-0097-4

Medjekal S, Bodas R, Bousseboua H \& López S (2017). Evaluation of three medicinal plants for methane production potential, fiber digestion and rumen fermentation in vitro. Energy Procedia 119: 632-641 https://doi.org/10.1016/j.egypro.2017.07.089

Mekuiko Watsop H, Tendonkeng F, Ngoula F, Miégoué E, Lemoufouet J, Fogang Zogang B, Chounna A, Mouchili M \& Pamo Tedonkeng E (2018). Effect of The essential oil of rhizomes of zingiber officinale on the in vitro digestibility of pennisetum clandestinum hay in small ruminants. International Journal of Current Innovations Research 4(1): 984-989

Meliani A, Nair S \& Bensoltane A (2014). Cyto-biochemical and antimicrobial investigations on essential oil of zingiber officinale roscoe. Journal of Essential Oil Bearing Plants 17(6): 1120-1129 https://doi.org/10.1080/0972060X.2014.986540

Menke K H, Raab L, Salewski A, Steingass H, Fritz D \& Schneider W (1979). The estimation of the digestibility and metabolizable energy content of ruminant feedingstuffs from the gas production when they are incubated with rumen liquor in vitro. Journal of Agricultural Sciences 93(1): 217-222 https://doi.org/10.1017/S0021859600086305

Menke K H \& Steingass H (1988). Estimation of the energetic feed value obtained from chemical analysis and in vitro gas production using rumen fluid. Animal Research and Development 28: 7-55

Nanon A, Suksombat W \& Yang W Z (2015). Use of essential oils for manipulation of rumen microbial fermentation using batch culture. Thai Journal of Veterinary Medicine 45(2): 167-180

NRC (National Research Council) (2007). Nutrient Requirements of Small Ruminants: Sheep, Goats, Cervids and New World Camelids. Washington, D.C.: National Academies Press

Raina V K, Kumar A \& Aggarwal K K (2005). Essential oil composition of ginger (zingiber officinale roscoe) rhizomes from different place in India. Journal of Essential Oil Bearing Plants 8(2): 187-191 https://doi.org/10.1080/0972060X.2005.10643442

Ratika K \& Singh R K J (2018). Plant derived essential oil in ruminant nutrition - A Review. International Journal of Current Microbiology and Applied Sciences 7(5): 1747-1753

SAS (Statistical Analysis Systems) (2004). SAS Procedures Guide. Release 9.1

Sharma P K, Singh V \& Ali M (2016). Chemical composition and antimicrobial activity of fresh rhizome essential oil of zingiber officinale roscoe. Pharmacognosy Journal 8(3): 185-190 https://doi.org/10.5530/pj.2016.3.3

Snedecor G W \& Cochran W G (1967). Statistical Methods, $7^{\text {th }}$ Edition. Iowa State Uni. Press

Soroor M E N \& Moeini M M (2015). The influence of ginger (zingiber officinale) on in vitro rumen fermentation patterns. Annual Review \& Research in Biology 5(1): 54-63 https://doi.org/10.9734/arrb/2015/12495

Tag El-Din A E, Moharam M S, Nour A A \& Nasser M E A (2012). Effect of some herbs on the rumen fermentation: 1-Effect of ginger (zingiber officinale) and garlic (allium sativum) on gas production, energy values, organic matter digestibility and methane emission, in vitro. Journal of Agriculture Environmental Science 11(2): 33-53

Takahashi J, Mwenya B, Santoso B, Sar C, Umetsu K, Kishimoto T, Nishizaki K, Kimura K \& Hamamoto O (2005). Mitigation of methane emission and energy recycling in animal agricultural systems. Asian-Australasian Journal of Animal Science 18(8): 1199-1208 
https://doi.org/10.5713/ajas.2005.1199

Van Soest P J, Robertson J B \& Lewis B A (1991). Methods for dietary fiber, neutral detergent fiber, and nonstarch polysaccharides in relation to animal nutrition. Journal of Dairy Science 74(10): 3583-3597 https://doi.org/10.3168/jds.S0022-0302(91)78551-2

Wiedmeier R D, Arambel M J \& Walters J L (1987). Effect of orally administered pilocarpine on ruminal characteristics and nutrient digestibility in cattle. Journal of Dairy Science 70(2): 284-289 https://doi.org/10.3168/jds.S0022-0302(87)80009-7

(C) 2021 by the authors. Licensee Ankara University, Faculty of Agriculture, Ankara, Turkey. This article is an open access article distributed under the terms and conditions of the Creative Commons Attribution (CC BY) license (http://creativecommons.org/licenses/by/4.0/). 